\title{
Rhodamine B and Rhodamine 6G Based Sensing of Copper Ions in Environmental and Biological Samples: Recent Progress
}

\author{
Santosh Dumbare ${ }^{1,2}$, Ashish Doshi ${ }^{1}$, Selvan Ravindran ${ }^{2 *}$ \\ ${ }^{1}$ Lupin Research Park, 46/47A, Village Nande, Taluka Mulshi, Pune-412115, Maharashtra, India \\ ${ }^{2}$ Faculty of Health Sciences, Symbiosis School of Biological Sciences, Symbiosis International (Deemed) University, \\ Lavale, Pune-412115, Maharashtra, India
}

Received: 17 August 2020

Accepted: 17 November 2020

\begin{abstract}
Metal ions are widely distributed in living organisms and environmental systems, therefore, their monitoring is of great importance. These days, several sophisticated instrumental methods are being used for the detection of metal ions; however, rapid recognition of metal ions requires powerful tools namely, colorimetric and fluorescent chemosensors. In this review, Rhodamine B and Rhodamine $6 \mathrm{G}$ based colorimetric and fluorescent chemosensors have been discussed. These methods are simple, involve low cost, lower detection limit, high selectivity, and sensitivity, thereby used to monitor real-time metal ions. Several metal ions were detected with high selectivity and sensitivity with the aid of various derivatives of Rhodamine $\mathrm{B}$ and Rhodamine $6 \mathrm{G}$ fluorophores conjugated to different ligands. Besides that, this review is focused on the detection of $\mathrm{Cu}^{2+}$ metal ions in recent years.
\end{abstract}

Keywords: sensors, chemosensors, rhodamine chemosensors, environmental samples, biological samples

\section{Introduction}

The design of high selectivity and sensitivity chemosensors for detecting the biologically and environmentally significant metal ions has captivated considerable attention [1-3]. Chemosensors signal the presence of a specific analyte of interest and are the molecules of abiotic origin. In mechanism, chemosensors bind to a particular analyte with high selectivity and reversibility which results in a change in some of the properties of the system, like absorption,

*e-mail: selvan_ravindran@yahoo.com fluorescence spectra, redox potentials, etc [4, 5]. Sophisticated instrumental methods like inductively coupled plasma mass spectrometry (ICP-MS), atomic absorption spectroscopy (AAS), spectrophotometry, voltammetry, ion chromatography, etc., could be used to detect certain metal ions. Even though these methods are exhaustive, the measurement involves high cost, requires extensive sample preparation, and is considered to be a time-consuming process [6-8]. Therefore, the development of reliable and efficient analytical methods for qualitative as well as quantitative detection of metal ions has drawn continuous research interest in many fields including materials, chemistry, environmental and biological sciences. Chemosensors are the powerful tools to monitor these metal ions in vivo and in vitro, 
<smiles></smiles>

Rhodamine B<smiles>CCN=c1cc2oc3cc(NCC)c(C)cc3c(-c3ccccc3C(=O)OCC)c-2cc1C</smiles>

Rhodamine $6 \mathrm{G}$

Fig. 1. Structures of Rhodamine B and Rhodamine 6G.

due to their high selectivity and sensitivity, simple operation, low cost, real-time monitoring ability, and short response time [7-10].

Rhodamine B (Fig. 1) is one of the most commonly used dyes which is widely used for labeling pigments, fluorescence standards, and chemosensors. Over the last few years, rhodamine-based probes have emerged as a matter of great interest due to its distinguished photophysical characteristics, namely high extinction coefficients, magnificent quantum yields, excellent photostability, and their ability to bind with various biologically important metal ions [11, 12]. This review focuses primarily on the identification of $\mathrm{Cu}^{2+}$ metal ions by Rhodamine $\mathrm{B}$ and Rhodamine $6 \mathrm{G}$ dependent chemosensors.

\section{Metal Ions Detection Using Rhodamine Chemosensors}

\section{Detection of $\mathrm{Cu}^{2+}$}

The third most common transition metal ion in the human organism is $\mathrm{Cu}^{2+}$ following $\mathrm{Fe}^{3+}$ and $\mathrm{Zn}^{2+}$. The function of several physiological processes of organisms and mammals is determined by copper ions [13]. $\mathrm{Cu}^{2+}$ is also involved with the active sites of nearly 20 metalloenzymes including laccase, $\mathrm{Cu} / \mathrm{Zn}$ superoxide dismutase, dopamine $\beta$-hydroxylase, tyrosinase, cytochrome c oxidase, and lysyl oxidase. Moreover, $\mathrm{Cu}^{2+}$ is an important micronutrient for all known living forms $[14,15]$. On the other hand, a high concentration of $\mathrm{Cu}^{2+}$ is also known to be toxic to living cells and it can cause severe neurodegenerative diseases like Menkes, Wilson, Alzheimer's, and Prion diseases [16]. High intake could also cause anemia and gastrointestinal distress and elevates the risk of lung cancer [17]. Many chemosensors have been reported for sensing $\mathrm{Cu}^{2+}$ [7, 18-23] but a convenient, fast, and accurate method is yet to be developed for its detection as this matter is of considerable importance. Sahoo's group reported chemosensor 1 for selective detection of $\mathrm{Cu}^{2+}$ in an aqueous medium [24]. In fluorometric titration between chemosensor 1 and $\mathrm{Cu}^{2+}$, enhancement of fluorescence was found to be 130-fold and observed at $574 \mathrm{~nm}$ with a very short response time of two minutes. Furthermore, chemosensor 1 (Table 1, Sensor 1) was effectively employed in spinach sapling for the estimation of copper (II) ions from its root, stem, and leaf of the sapling.

Yang et. al developed and synthesized a tetraphenylethene (TPE)-rhodamine hydrazoneconjugate 2 via condensation of rhodamine $\mathrm{B}$ hydrazide 2-hydroxy-5-(1,2,2-triphenylvinyl)benzaldehyde [25]. Chemosensor 2 (Table 1, Sensor 2) exhibited aggregation-induced emission behavior in more than $40 \%$ water fraction. Upon addition of $\mathrm{Cu}^{2+}$, the absorbance intensity was remarkably enhanced and the solution's color changed from colorless to purple with 1:1 metal-probe complex formation. Moreover, the binding of chemosensor to $\mathrm{Cu}^{2+}$ was found chemically reversible by adding an EDTA solution. Ding et. al. reported a fluorescent diarylethenerhodamine derivative 3 to identify $\mathrm{Cu}^{2+}$ and arginine [26] sequentially. Rhodamine derivative 3 (Table 1, Sensor 3) exhibited "turn-on" fluorescence response selectively towards $\mathrm{Cu}^{2+}$ in acetonitrile-water (4/1, v/v) media. A linear response was established between $\mathrm{Cu}^{2+}$ concentration and fluorescence intensity within the 2-36 $\mu \mathrm{M}$ range. Fluorescence response of $3-\mathrm{Cu}^{2+}$ got quenched with the addition of arginine over other 17 amino acids which demonstrated that sensor 3 has high selectivity towards arginine only.

\section{Selective Detection of Copper Ions $\left(\mathrm{Cu}^{2+}\right)$ in Solvents}

Wang's group reported a rhodamine 6G-based probe 4 (Table 1, Sensor 4) which exhibited selective response towards $\mathrm{Cu}^{2+}$ in acetonitrile over the other background metal ions [27]. Upon addition of 6 equivalents of $\mathrm{Cu}^{2+}$ to 4 , a spirocyclic ring of rhodamine unit was opened, resulting in 250-fold fluorescence enhancement at $557 \mathrm{~nm}$ with a transition in color to purple, aids in the identification of $\mathrm{Cu}^{2+}$ through naked-eye. The detection threshold for $\mathrm{Cu}^{2+}$ was $2.5 \mu \mathrm{M}$ when the probe $4-\mathrm{Cu}^{2+}$ complex stoichiometry was $1: 1$. Wang et. al reported a dual-function optical chemosensor 5 (Table 1, Sensor 5) through condensation of 5-Hydroxymethylfurfural and rhodamine B hydrazide [28]. Chemosensor 5 showed a specific fluorescent response towards acidic $\mathrm{pH}$. Fluorescence intensity of 5 was enhanced by 41 times between $\mathrm{pH} 7.50$ and 3.73 with a $\mathrm{pKa}$ value of 5.02 and a change of color from colorless to pink. Furthermore, UV-Vis spectroscopy study and addition of EDTA 
Table 1. Chemosensor structure, detection limit and references for $\mathrm{Cu}^{2+}$.

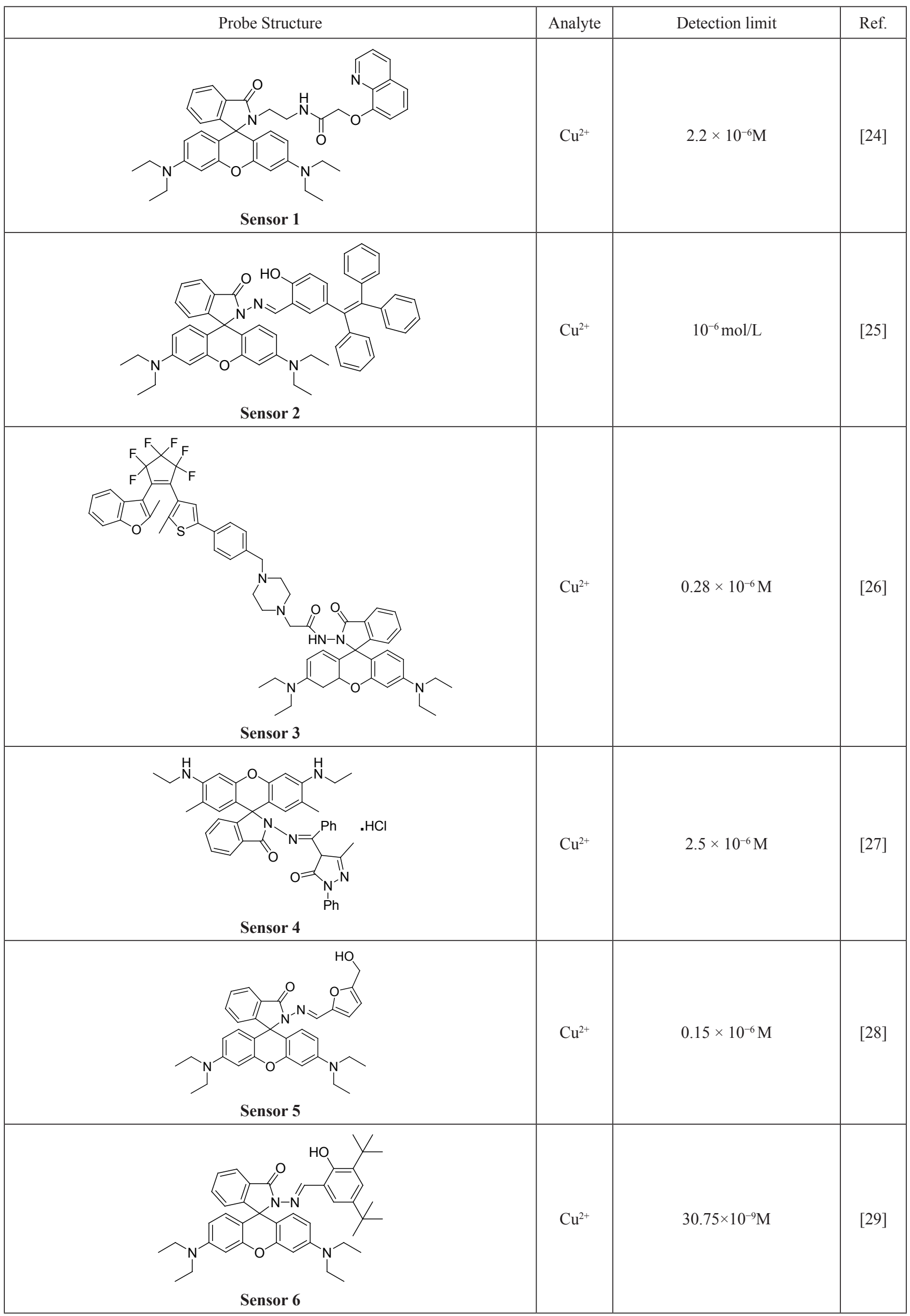


Table 1. Continued.

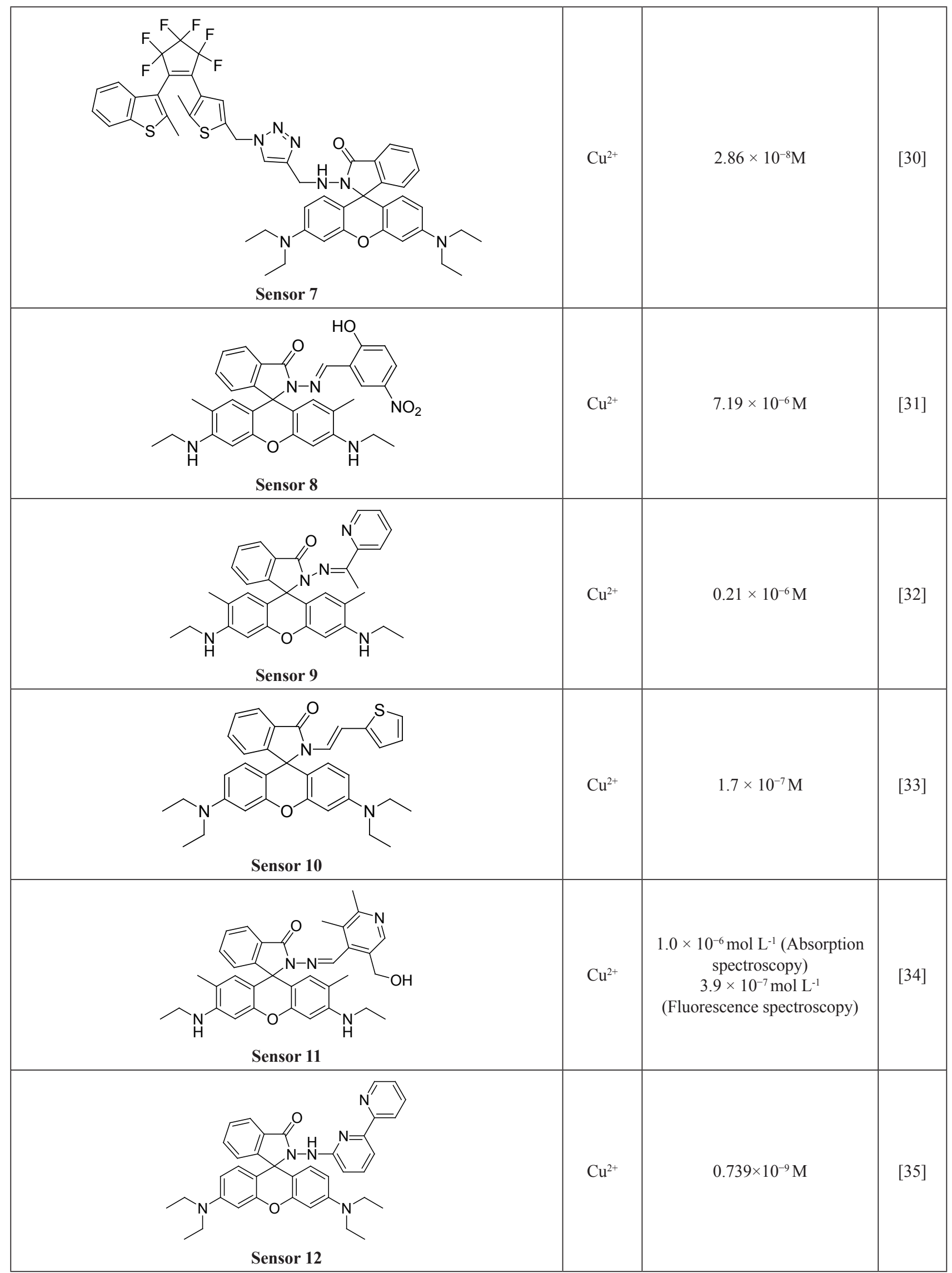


Table 1. Continued.

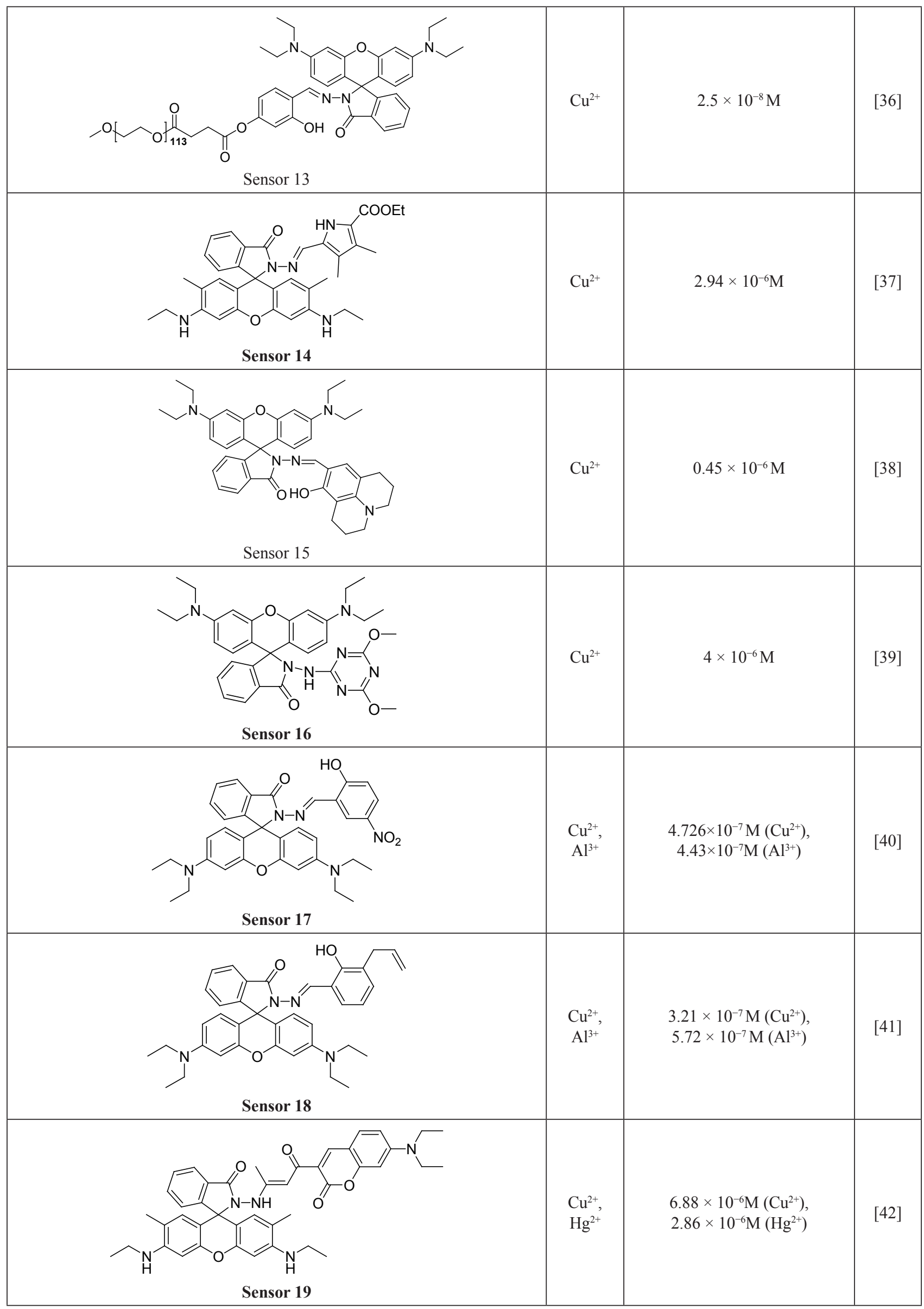


Table 1. Continued.

(1)

experiments showed selectivity and reversibility of probe towards $\mathrm{Cu}^{2+}$ in Tris- $\mathrm{HCl}(10 \mathrm{mM}, \mathrm{pH}=7.2)$ over the other metal ions. A study using Job's plot recorded a 1:2 binding stoichiometry between $\mathrm{Cu}^{2+}$ and probe 5 .

Chattopadhyay's group synthesized a "turn on" colorimetric and fluorimetric probe 6 (Table 1, Sensor 6) to detect $\mathrm{Cu}^{2+}$ ions selectively as low as nanomolar levels in an aqueous medium [29]. The 68-fold increase was observed in fluorescence intensity because of the ring-opening of the rhodamine-B spirolactam network with a color shift to reddish-pink when 3 equivalents of $\mathrm{Cu}^{2+}$ was added. The cell imaging study using a fluorescence microscope showed that the probe is noncytotoxic and it is useful to recognize the distribution of $\mathrm{Cu}^{2+}$ ions in live cells.

Xue et. al designed and developed a rhodamine B-consisting diarylethene probe 7 [30]. Fluorescent emission of probe 7 (Table 1, Sensor 7) was remarkably intensified in the presence of protons or $\mathrm{Cu}^{2+}$ due to the formation of the rhodamine moiety open-ring. The association constant for $7-\mathrm{Cu}^{2+}$ was $2.86 \times 10^{6} \mathrm{~L} \mathrm{~mol}^{-1}$. The probe was employed effectively for real water sample analysis by spiking an appropriate amount of $\mathrm{Cu}^{2+}$, where \% recovery was reported to be 98.6 to $110.9 \%$.

\section{Detection of Copper ions $\left(\mathrm{Cu}^{2+}\right)$ in the Presence of Environmentally and Biologically Important Metal Ions}

Bharadwaj and co-workers developed a new rhodamine $6 \mathrm{G}$ derived probe 8 (Table 1 , Sensor 8 ) to detect $\mathrm{Cu}^{2+}$ ion over the other environmentally relevant and biologically important metal ions in ethanol-water
$(1: 1, \mathrm{v} / \mathrm{v})$ media at physiological $\mathrm{pH}(\mathrm{pH} 7.2)$ [31]. Probe 8 bound selectively to $\mathrm{Cu}^{2+}$ in $1: 1$ stoichiometry. The detection limit for $\mathrm{Cu}^{2+}$ ion was stated to be $7.19 \mu \mathrm{M}$ which is below the permitted limit for $\mathrm{Cu}^{2+}$ in drinking water $(20 \mu \mathrm{M})$ set by USEPA. A cell imaging research further revealed that the probe could serve as a possible candidate for the selective $\mathrm{Cu}^{2+}$ ion recognition in living cells. Liu et al. reported a novel fluoro-chromogenic rhodamine 6G-pyridine conjugate 9 (Table 1, Sensor 9) for selective $\mathrm{Cu}^{2+}$ sensing over other metal ions [32]. After, adding a solution of $\mathrm{Cu}^{2+}$ to 9, a "turn-on" response was observed with a remarkable color change from colorless to red. The response of fluorescence intensity of 9 was found linear to $\mathrm{Cu}^{2+}$ concentration from 2.0 to $20.0 \mu \mathrm{M}$ with a binding stoichiometry of 2:1. Further, the probe was tested for sensing of $\mathrm{Cu}^{2+}$ in natural water and the recovery was compared with the one obtained by ICP-AES. Comparable recovery results indicated the great potential of a probe for monitoring of $\mathrm{Cu}^{2+}$ in real sample analysis.

\section{Identification of Copper Ions $\left(\mathrm{Cu}^{2+}\right)$ in Aqueous Media}

Yang et al. engineered and synthesized a new "off-on" colorimetric rhodamine derivative 10 (Table 1, Sensor 10) possessing thiophene group, for $\mathrm{Cu}^{2+}$ identification in aqueous media with high precision [33]. A strong linear response was obtained from $1.0 \times 10^{-6}$ to $1.0 \times 10^{-5} \mathrm{~mol} / \mathrm{L}$ between the absorption strength of 10 and $\mathrm{Cu}^{2+}$ concentration. Upon incremental addition of $\mathrm{Cu}^{2+}$ from $0-4$ equivalents to the solution of 10, an absorption band emerged at $561 \mathrm{~nm}$ shifting the colorless solution to pink. A rhodamine $6 \mathrm{G}$-based 
chemosensor 10 reported by Huang et al. exhibited a rapid $\mathrm{Cu}^{2+}$ ion identification in an aqueous medium with a color transition towards pink [34]. Chemosensor 11 (Table 1, Sensor 11) showed a very low fluorescence response in the $\mathrm{pH}$ range of 2.5-10.5; however, after the addition of $\mathrm{Cu}^{2+}$, significant fluorescence enhancement with $\mathrm{pH}$ of 3.5 to 7.5 due to the opening of the rhodamine spirolactam unit. Furthermore, the fluorescence intensity of $11-\mathrm{Cu}^{2+}$ was quenched when the EDTA solution was added, indicating the reversibility of the sensing process.

Yuan et al. developed a "turn-on" fluorescent probe 12 (Table 1, Sensor 12) for $\mathrm{Cu}^{2+}$ [35]. For rapid detection of $\mathrm{Cu}^{2+}$ an air-dried filter paper from the solution of 12 was immersed in an aqueous solution of $\mathrm{Cu}^{2+}$ for several seconds; interestingly, the color of the test strips shifted to purple from colorless with a detection limit of $10 \mu \mathrm{M}$ lower than the approved $\mathrm{Cu}^{2+}$ limit in drinking water $(1 \mathrm{mg} / \mathrm{L})$ as set by the WHO (World Health Organization). Furthermore, an imaging study showed that probe 12 could be used to detect $\mathrm{Cu}^{2+}$ in living cells. A novel water-soluble polymer-based (polyethylene glycol) reversible colorimetric probe 13 (Table 1, Sensor 13) developed by Li's group showed a rapid response towards $\mathrm{Cu}^{2+}$ in pure aqueous solution [36]. The chemosensor could detect $\mathrm{Cu}^{2+}$ over a wide range of $\mathrm{pH} 4-10$. After the addition of $\mathrm{Cu}^{2+}$, a colorless solution of probe 13 turned to purple within a very short time of $5 \mathrm{~s}$, indicating that the probe could be used to detect $\mathrm{Cu}^{2+}$ ions in real-time. Association constant of probe 13 coordinated with $\mathrm{Cu}^{2+}$ was determined to be $1.01 \times 10^{5} \mathrm{M}^{-1}$.

\section{Sensing Copper Ions $\left(\mathrm{Cu}^{2+}\right)$ in the Presence of Other Background Metal Ions}

Wang et al. reported a ratiometric and fluorescent sensor 14 (Table 1, Sensor 14) Rhodamine 6G hydrazine coordinated to the pyrrole unit, for $\mathrm{Cu}^{2+}$ sensing [37]. Probe 14 could be used as a dual-mode sensor. It detects $\mathrm{Cu}^{2+}$ from sensor 14- $\mathrm{Cd}^{2+}$ complex utilizing ringopening mechanism and by ratiometric displacement of $\mathrm{Cd}^{2+}$ ion. The addition of $\mathrm{Cu}^{2+}$ to the solution of 14 exhibited a significant change in absorbance and fluorescence emission at $525 \mathrm{~nm}$ and $550 \mathrm{~nm}$ respectively, owing to cleavage of spirolactam bond of rhodamine unit. Furthermore, the incremental addition of $\mathrm{Cu}^{2+}$ to $14-\mathrm{Cd}^{2+}$ solution, displaces $\mathrm{Cd}^{2+}$ to form 14- $\mathrm{Cu}^{2+}$ complex indicating ratiometric displacement. $\mathrm{Li}$ et. al developed a novel colorimetric probe 15 (Table 1, Sensor 15) from 8-hydroxyjulolidine as source material [38]. Chemosensor 15 showed high selectivity towards $\mathrm{Cu}^{2+}$ ions and also exceptional anti-interference ability over the other background metal ions. A 1:1 complex coefficient of 15 to $\mathrm{Cu}^{2+}$ was determined by Job's plot analysis. A good linear working range was recorded using 15 for $\mathrm{Cu}^{2+}$ from $0-50 \mu \mathrm{M}$ with a sensing cap of $0.45 \mu \mathrm{M}$ which is $2 \%$ of the permissible drinking water level of $20 \mu \mathrm{M}$ as defined by the US EPA.
Simultaneous Identification of Copper Ions $\left(\mathrm{Cu}^{2+}\right)$ and Aluminium Ions $\left(\mathrm{Al}^{3+}\right)$

Zhang and co-workers reported a convenient and highly selective probe 16 (Table 1 , Sensor 16) for $\mathrm{Cu}^{2+}$, and its chemosensing properties were investigated [39]. An unperturbed absorption spectrum of 16 was noticed in the range of $\mathrm{pH}$ 4.0-9.0, indicating that 16 could be used for sample study over an extensive range of $\mathrm{pH}$. With $\mathrm{Al}^{3+}$ being added to the probe 16 solution, a marked rise in fluorescence emerged with emission maxima at $580 \mathrm{~nm}$. Interestingly, on the addition of $\mathrm{Cu}^{2+}$ to $16-\mathrm{Al}^{3+}$, fluorescence produced with $\mathrm{Al}^{3+}$ disappeared and a unique stable absorption band originated at $564 \mathrm{~nm}$ probably due to the paramagnetic effect of the $d_{9} \mathrm{Cu}^{2+}$ ion. Son's group designed and synthesized 4-nitrosalicylaldiminebased "OFF-ON-OFF" dual reversible sensor 17 with rhodamine $\mathrm{B}$ for sensing of $\mathrm{Cu}^{2+}$ and $\mathrm{Al}^{3+}$ ions [40]. The chemosensor 17 (Table 1, Sensor 17) exhibited fluorescence and optical preference for $\mathrm{Al}^{3+}$ and $\mathrm{Cu}^{2+}$ in dimethyl sulfoxide-water media over the other common metal ions respectively. With the addition of $\mathrm{CN}^{-}$and EDTA, the color of $17-\mathrm{Cu}^{2+}$ complex diminished, whereas the fluorescent nature of $17-\mathrm{Al}^{3+}$, "turned-off" due to the influence of EDTA. The binding constants of $17-\mathrm{Cu}^{2+}$ and $17-\mathrm{Al}^{3+}$ were reported to be $2.18 \times 10^{5}$ and $2.76 \times 10^{4} \mathrm{M}^{-1}$ with a binding stoichiometry of 1:1.

\section{Detection of Copper Ions $\left(\mathrm{Cu}^{2+}\right)$ in the Presence of Aluminium Ions $\left(\mathrm{Al}^{3+}\right)$}

Rai et al. reported a probe 18 (Table 1, Sensor 18) synthesized from rhodamine $\mathrm{B}$ hydrazide and allylsalicylaldehyde for $\mathrm{Cu}^{2+}$ and $\mathrm{Al}^{3+}$ identification in aqueous media [41]. With the introduction of 10.0 Equiv. of $\mathrm{Cu}^{2+}$ and $\mathrm{Al}^{3+}$ ions to probe 18 solutions, a unique band emerged at $552 \mathrm{~nm}$ and $559 \mathrm{~nm}$, respectively, in the UV-Vis spectrum. A "turn-on" fluorescence response appeared with a new band at $587 \mathrm{~nm}$ when $\mathrm{Al}^{3+}$ was added to a solution of 18. Quenching of fluorescence of open-ring form of rhodamine was observed due to chelation enhanced fluorescence quenching (CHEQ). The binding constants for $\mathrm{Cu}^{2+}$ and $\mathrm{Al}^{3+}$ were calculated to be $6.2 \times 10^{4} \mathrm{M}^{-1}$ and $1.4 \times 10^{4} \mathrm{M}^{-1}$, respectively. $\mathrm{Xu}$ et al. synthesized probe 19 (Table 1, Sensor 19) based on Rhodamine 6G hydrazone coordinated to coumarin unit at a particular $\mathrm{pH}$ for the sensing of $\mathrm{Cu}^{2+}$ and $\mathrm{Hg}^{2+}$ [42]. The probe detected $\mathrm{Cu}^{2+}$ with high selectivity in neutral aqueous media, whereas, $\mathrm{Hg}^{2+}$ was detected with fluorescence enhancement at $\mathrm{pH} 10$. Fluorescence intensity linearly corresponds to $\mathrm{Cu}^{2+}$ ion concentration ranging from $8-15 \mu \mathrm{M}$ and absorbance was directly proportional to the quantity of $\mathrm{Cu}^{2+}$ ions in the range of 0-30 $\mu \mathrm{M}$. Upon introduction of 17 Equiv. of $\mathrm{Hg}^{2+}$ to $5 \mu \mathrm{M}$ of probe 19 in acetonitrile/water $(9 / 1, \mathrm{v} / \mathrm{v}$, $\mathrm{pH}$ 10.0) media, an enhanced emission band with a fluorescence intensity appeared at $498 \mathrm{~nm}$ concerning the concentration of $\mathrm{Hg}^{2+}$ ions ranging from $0-20 \mu \mathrm{M}$. 
Table 2: Pros and cons of sensing and spectroscopic methods.

\begin{tabular}{|c|c|c|c|}
\hline & Sensing Methods & Pros & Cons \\
\hline 1 & Chemosensors & $\begin{array}{l}\text { (1) Convenient for In Vivo real-time imaging studies } \\
\text { (2) High selectivity and Sensitivity } \\
\text { (3) Rapid detection and easy to operate } \\
\text { (4) Sample preparation procedures are not complex } \\
\text { (5) Convenient for the onsite analysis } \\
\text { (6) Few of the chemosensors are reversible } \\
\text { (7) Each chemosensor is specific for a particular } \\
\text { cation or anion } \\
\text { (8) Do not occupy large space } \\
\text { (9) Long shelf life and Cost-effective } \\
\text { (10) Low power requirements or nil }\end{array}$ & $\begin{array}{l}\text { (1) Detection is pH-dependent } \\
\text { (2)Different chemosensors are needed for } \\
\text { specific detection } \\
\text { (3) Atomic weight of metals cannot be } \\
\text { determined }\end{array}$ \\
\hline 2 & Electrochemical Sensors & $\begin{array}{l}\text { (1) Specific for analyzing gases and some of the } \\
\text { cations }\end{array}$ & $\begin{array}{l}\text { (1) Sensitive to temperature } \\
\text { (2) Shelf life is limited } \\
\text { (3) Cross-reactivity due to other gases } \\
\text { (4) Electrolytes are reduced due to very high } \\
\text { temperature and low humidity }\end{array}$ \\
\hline & Spectroscopic methods & Pros & Cons \\
\hline 3 & $\begin{array}{l}\text { Atomic Absorption } \\
\text { Spectroscopy }\end{array}$ & $\begin{array}{l}\text { (1) Quantitative analysis } \\
\text { (2) Selective and sensitive }\end{array}$ & $\begin{array}{l}\text { (1) Requires different filters for the detection } \\
\text { of different metal ions } \\
\text { (2) Onsite analysis is not possible } \\
\text { (3) Trained personnel are needed for sample } \\
\text { processing and operating the instruments } \\
\text { (4) Occupy large space in laboratories } \\
\text { (5) High working cost }\end{array}$ \\
\hline 4 & $\begin{array}{l}\text { Inductively coupled } \\
\text { plasma mass } \\
\text { spectrometry (ICP-MS) }\end{array}$ & $\begin{array}{l}\text { (1) Identification of atomic weight of elements } \\
\text { (2) Used for simultaneous detection of different } \\
\text { elements } \\
\text { (3) Selective and sensitive }\end{array}$ & $\begin{array}{l}\text { (1) High working cost } \\
\text { (2) Onsite analysis is not possible } \\
\text { (3) Trained personnel are needed and require } \\
\text { large space in laboratories }\end{array}$ \\
\hline 5 & $\begin{array}{l}\text { X-ray photoelectron } \\
\text { spectroscopy (XPS) }\end{array}$ & $\begin{array}{l}\text { (1) To determine the binding energy of a particular } \\
\text { element. } \\
\text { (2) Surface chemistry of metals }\end{array}$ & $\begin{array}{l}\text { (1) Ultra-high vacuum is needed for analysis } \\
\text { (2)Trained personnel are needed for sample } \\
\text { processing and operating the instruments } \\
\text { (4) Maintenance cost is high } \\
\text { (5) Not feasible for onsite analysis }\end{array}$ \\
\hline 6 & $\begin{array}{l}\text { Electron spin resonance } \\
\text { spectroscopy }\end{array}$ & $\begin{array}{l}\text { (1)To detect metals with unpaired electrons or free } \\
\text { radicals. } \\
\text { (2) Useful for studies of complex macromolecules } \\
\text { like proteins with the metal clusters. }\end{array}$ & $\begin{array}{l}\text { (1) Sample solution must contain } \\
\text { paramagnetic species } \\
\text { (2) Maintenance cost is high }\end{array}$ \\
\hline 7 & Mossbauer spectroscopy & (1) Specifically, to analyze iron & (1) Needs suitable gamma-ray source \\
\hline 8 & $\begin{array}{l}\text { Ion exchange } \\
\text { chromatography }\end{array}$ & $\begin{array}{l}\text { (1) Useful for simultaneous separation, detection, } \\
\text { and quantification of different metal ions } \\
\text { (2) Amino acids, nucleotides, and large proteins can } \\
\text { also be separated }\end{array}$ & $\begin{array}{l}\text { (1) Requires specific columns for separation } \\
\text { (2) Need buffer solutions for separation } \\
\text { (3) Inconvenient for onsite analysis } \\
\text { and maintenance cost is high }\end{array}$ \\
\hline
\end{tabular}

\section{Detection of Copper Ions $\left(\mathrm{Cu}^{2+}\right)$ in the Presence of Mercury Ions $\left(\mathrm{Hg}^{2+}\right)$}

Zang and co-workers developed a dual chemosensor 20 i.e rhodamine $\mathrm{B}$ with an $\mathrm{NS}_{2}$-containing receptor (Table 1, Sensor 20) to sense $\mathrm{Hg}^{2+}$ and $\mathrm{Cu}^{2+}$ ions in aqueous media [43]. Chemosensor 20 exhibited a colorimetric response towards $\mathrm{Cu}^{2+}$, whereas the "turn-on" fluorescent response showed for $\mathrm{Hg}^{2+}$. Chemosensor 20 exhibited $\mathrm{pH}$-independent response towards $\mathrm{Cu}^{2+}$ and $\mathrm{Hg}^{2+}$ over a wide range of $\mathrm{pH} 4.0$ 9.0. Upon interaction with $\mathrm{Cu}^{2+}$, chemosensor 20 showed a 251-fold absorption enhancement along with a visually detectable change from uncolored to purple.
Wang's group reported a polymer-based water-soluble dual-mode chemosensor 21 (Table 1, Sensor 21) for sensing of $\mathrm{Cu}^{2+}$ and $\mathrm{Hg}^{2+}$ in a $100 \%$ aqueous solution [44]. Probe 21 exhibited not only colorimetric response to $\mathrm{Cu}^{2+}$ and $\mathrm{Hg}^{2+}$ but also a selective turn-on fluorescent response to $\mathrm{Hg}^{2+}$ over the other metal ions that coexist. The binding stoichiometries of $21-\mathrm{Cu}^{2+}$ and $21-\mathrm{Hg}^{2+}$ using Job's plot analysis were found to be in the ratio of 1:1. Furthermore, the test papers coated with the solution of probe 21 were found relevant for the on-site identification of $\mathrm{Hg}^{2+}$ and $\mathrm{Cu}^{2+}$ and ions in actual water samples. The pros and cons of sensing methods and spectroscopic methods are shown in Table 2. 


\section{Future Perspectives}

Chemosensors are organic and susceptible to biodegradation similar to pharmaceutical drugs in the human system [45]. Organic pharmaceutical compounds undergo metabolism by enzymes [46] and used as a therapy, similarly chemosensors can be biodegraded for or after its specific applications [47]. Chemosensors can be effectively utilized to detect and harvest metal ions from biological and environmental matrices, where copper ions are a major cause of environmental concern [48]. Accumulated metallic wastes can be effectively isolated, segregated, and purified for reuse with the assistance of chemosensors.

\section{Conclusions}

In this review, recently reported colorimetric and fluorescent sensors originated from Rhodamine B and Rhodamine 6G are summarized. The sensors were classified according to their sensing capability towards specific copper ion. Binding stoichiometry and association constants of some of the sensormetal complexes were described. Most of the sensors fulfilled the minimum detection limit of these metal ions required by USEPA at physiological $\mathrm{pH}$ range in aqueous media. Therefore, sensors fulfilling the criteria set by USEPA were employed to image the cells, and the maximum number of sensors was found to be low or non-toxic with better permeability. More researchers are focused on this creative area of research to develop novel, selective and sensitive sensors for detecting various environmentally and biologically important metal ions.

\section{Acknowledgements}

Santosh Dumbare is thankful to Lupin Research Park ( $\mathrm{R}$ and $\mathrm{D}$ division of Lupin Limited) for providing a platform for higher education under ASCENT program. Authors are thankful to Dr. Vinay Rale and Dr. Anuradha Vaidya, Symbiosis School of Biological Sciences for valuable suggestions

\section{Conflict of Interest}

The authors declare no conflict of interest.

\section{References}

1. FORMICA M., FUSI V., GIORGI L., MICHELONI M. New fluorescent chemosensors for metal ions in solution. Coordination Chemistry Reviews, 256 (1-2), 170, 2012.

2. ABEBE F., GONZALEZ J., MAKNIS-DENNIS K., SHAW R. A new bis(rhodamine)-based colorimetric chemosensor for $\mathrm{Cu}^{2+}$. Inorganic Chemistry Communications, 120, 108154, 2020.

3. BERHANU A.L., GAURAV I., MOHIUDDIN A.K., MALIK J.S., AULAK V.K., KIM K.H. A review of the applications of the Schiff bases as optical sensors. TrAC Trends in Analytical Chemistry, 116, 74, 2019.

4. PRODI L., BOLLETTA M., MONTALTI M., ZACCHERONI N. Luminescent chemosensors for transition metal ions. Coordination Chemistry Reviews, 205 (1), 59, 2000.

5. LIU S., WANG Y.M., HAN J. Han. Fluorescent chemosensors for copper (II) ion: Structure, mechanism and application. Journal of Photochemistry and Photobiology C: Photochemistry Reviews, 32, 78, 2017.

6. ZHANG N., QIAO R., SU J.Y., XIE Z., QIAO Y., WANG $X .$, ZHONG J. Recent advances of electrospun nanofibrous membranes in the development of chemosensors for heavy metal detection. Small, 13 (16), 1604293(1), 2017.

7. UDHAYAKUMARI D., NAHA S., VELMATHI S. Colorimetric and fluorescent chemosensors for $\mathrm{Cu} 2+$. A comprehensive review from the years 2013-2015. Analytical Methods, 9, 552, 2017.

8. KIM H.N., REN W.X., KIM J.S., YOON J. Fluorescent and colorimetric sensors for detection of lead, cadmium, and mercury ions. Chem. Soc. Rev., 41, 3210, 2012.

9. ZHANG J.F., ZHOU Y., YOON J., KIM J.S. Recent progress in fluorescent and colorimetric chemosensors for detection of precious metal ion (silver, gold and platinum ions). Chemical Society Reviews, 40 (7), 3416, 2011.

10. QUANG D.T., KIM, J.S. Fluoro- and chemogenic chemodosimeters for heavy metal ion detection in solution and biospecimens. Chemical Reviews, 110 (10), 6280, 2010.

11. ADAK A.K., DUTTA B., MANNA S.K., SINHA C. Rhodamine-appended benzophenone probe for trace quantity detection of $\mathrm{Pd}^{2+}$ in living cells. ACS Omega, 4(21), 18987, 2019.

12. YANG Y., GAO C.Y., LIU, J., DONG, D. Recent developments in rhodamine salicylidence hydrazine chemosensors. Analytical Methods, 8, 2863, 2016.

13. DENOYER D., MASALDAN S., LA FONTAINE S., CATER M.A. Targeting copper in cancer therapy: Copper that cancer. Metallomics, 7 (11), 1459, 2015.

14. SOLOMON E.I., HEPPNER D.E., JOHNSTON M.E., GINSBACH J.W., CIRERA J., QAYYUM M., KIEBEREMMONS M.T., KJAERGAARD C.H., HADT R.G., TIAN L. Copper active sites in biology. Chemical Reviews, 114, 3659, 2014.

15. ZHOU G., JI X., CUI N., CAO S., LIU C., LIU J. Association between serum copper status and working memory in schoolchildren. Nutrients, 7 (9), 7185, 2015.

16. KOZLOWSKI H., LUCZKOWSKI M., REMELLI M., VALENSIN D. Copper, zinc and iron in neurodegenerative diseases (Alzhemeir's, Parkinson's and prion diseases). Coordination Chemistry Reviews, 256 (19-20), 2129, 2012.

17. "Toxicological Profile of Copper". Agency for toxic substances and disease registry, U.S. Department of Health and Human Services. Retrieved 17 June 2015.

18. CHANDRASHEKAR V., DAS S., YADAV R., HOSSAIN S., PARIHAR R., SUBRAMANIAM G., SEN P. Novel chemosensor for the visual detection of copper(II) in aqueous solution at the ppm level. Inorganic Chemistry, $\mathbf{5 1}$ (16), 8664, 2012.

19. LOPEZ-SERRANO D., SOLANO F., SANCHEZ A.D. Involvement of a novel copper chaperone in tyrosinase 
activity and melanin synthesis in Marinomonas mediterranea. Microbiology, 53, 2241, 2007.

20. MARTINEZ R., ESPIONASA A., TARRAGE A., MOLINA P. Bis(indolyl)methane derivatives as highly selective colourimetric and ratiometric fluorescent molecular chemosensors for $\mathrm{Cu}^{2+}$ cations. Tetrahedron, $\mathbf{6 4}$, 2184, 2008

21. HASFALINA C.M., MARYAM R.Z., LUQMAN A., RASHID M. Adsorption of copper (II) from medium in fixed bed column by kenaf fibres. APCBEE Procedia, 3, $255,2012$.

22. MAJUMDAR A., LIM C.S., KIM H.M., GHOSH K. New six-membered $\mathrm{pH}$-insensitive rhodamine spirocycle in selective sensing of $\mathrm{Cu}^{2+}$ through $\mathrm{C}-\mathrm{C}$ bond cleavage and its application in cell imaging. ACS Omega, 2 (11), 8167, 2017.

23. JEONG J., RAO B., SON Y.A. Dual sensing performance of a rhodamine-derived scaffold for the determination of $\mathrm{Cu}^{2+}$ and $\mathrm{Ce}^{4+}$ in aqueous media. Sensors and Actuators B: Chemical, 220, 1254, 2015.

24. DAS S., RISSANEN K., SAHOO P. Rare crystal structure of open spirolactam ring along with the closed-ring form of a rhodamine derivative: Sensing of $\mathrm{Cu}^{2+}$ from spinach. ACS Omega, 4 (3), 5270, 2019.

25. YANG C., GAO Y., LI T., CHEN J -Y. GAO. A tetraphenylethene-based rhodamine hydrazone chemosensor for colorimetric and reversible detection of $\mathrm{Cu}^{2+}$. ChemistrySelect, 1 (15), 4577, 2016.

26. DING H., LI B., PU S., LIU G., JIA D., D. ZHOU Y. A fluorescent sensor based on a diarylethene-rhodamine derivative for sequentially detecting $\mathrm{Cu}^{2+}$ and arginine and its application in keypad lock. Sensors and Actuators B: Chemical, 247, 26, 2017.

27. LI T., YANG Y., ZHOU P., PENG Z., QIN J., LIU L., WANG Y. A rhodamine 6G derivative as "turn-on" fluorescent probe for $\mathrm{Cu}^{2+}$ spectroscopy, single crystal structure and DFT calculations. Polyhedron, 128, 154, 2017.

28. WANG E., ZHOU Y., HUANG Q., PANG L., QIAO H., YU F., GAO B., ZHANG J., MIN Y., MA T. 5-Hydroxymethylfurfural modified rhodamine B dualfunction derivative: Highly sensitive and selective optical detection of $\mathrm{pH}$ and $\mathrm{Cu}^{2+}$. Spectrochimica Acta Part A: Molecular and Biomolecular Spectroscopy, 152, 327, 2016.

29. MAJI A., LOHAR S., PAL S., CHATTOPADHYAY P. A new rhodamine based 'turn-on' $\mathrm{Cu}^{2+}$ ion selective chemosensor in aqueous system applicable in bioimaging. Journal of Chemical Sciences, 129, 1423, 2017.

30. XUE D., XUE D., ZHENG C., QU S., LIAO G,; FAN C., LIU G., PU S. A highly selective fluorescent chemosensor for $\mathrm{Cu}^{2+}$ : synthesis and properties of a rhodamine B-containing diarylethene, Luminescence, 32, 652, 2017.

31. CHATTERJEE CN., MAHALING B., SIVAKUMAR S., BHARADWAJ P.K. A highly selective and sensitive "Turn-On" fluorescence chemosensor for the $\mathrm{Cu}^{2+}$ ion in aqeous ethanolic medium and its application in live cell imaging. Journal of Photochemistry and Photobiology A: Chemistry, 330, 110, 2016.

32. LIU K., XU S., GUO P., LIU L., SHI X., ZHU B. A novel chromogenic $\mathrm{Cu}^{2+}$ probe for living-cell imaging based on rhodamine 6G-pyridine conjugation. A novel fluoro-c Analytical and Bioanalytical Chemistry, 411, 3021, 2019.

33. YANG Z., ZHAO S., CHEN Y., BU X., ZHU Y., DU Y., LI F.A highly sensitive and selective colorimetric
"Off-On" chemosensor for $\mathrm{Cu}^{2+}$ in aqueous media based on a rhodamine derivative bearing thiophene group. Sensors and Actuators B: Chemical, 235, 414, 2016.

34. HUANG Q., CHEN Y.T., REN Y.W., WANG Z.Y., ZHU YX., ZHANG Y. Zhang. A rapid and naked-eye visible rhodamine 6G-based chemosensor for sensitive detection of copper (II) ions in aqueous solution. Analytical Methods, 10 (47), 5731, 2018.

35. YUAN Y., SUN S., LIU S., SONG X., PENG X. Highly sensitive and selective turn-on fluorescent probes for $\mathrm{Cu}^{2+}$ based on rhodamine B. Journal of Materials Chemistry B, 3 (26), 5261, 2015.

36. LI G., TAO F., LIU Q., WANG L., WEI Z., ZHU F., CHEN W., SUN H., ZHOU Y. A highly selective and reversible water-soluble polymer based colorimetric chemosensor for rapid detection of $\mathrm{Cu}^{2+}$ in pure aqueous solution. New Journal of Chemistry, 240 (5), 4513, 2016

37. WANG Y., CHANG H.Q., WU W.N., PENG W. B., YAN Y.F., HE C.M. CHEN T.T., ZHAO X.L. ZHU Z.Q. Rhodamine $6 \mathrm{G}$ hydrazone bearing pyrrole unit: Ratiometric and selective fluorescent sensor for $\mathrm{Cu}^{2+}$ based on two different approaches. Sensors and Actuators B: Chemical, 228, 395, 2017.

38. LI C., XIANG K., LIU Y., ZHENG Y., TIAN B., ZHANG J. A novel colorimetric chemosensor for $\mathrm{Cu}^{2+}$ with high selectivity and sensitivity based on Rhodamine B. Research on Chemical Intermediates, 41, 10169, 2015.

39. ZHANG D., MA Y., AN R. New colorimetric chemosensor based on rhodamine hydrazide to detect $\mathrm{Cu}^{2+}$ ions by naked eye. Research on Chemical Intermediates, 41, 5059, 2015.

40. KIM H.S., ANGUPILlAI S., SON Y.A. A dual chemosensor for both $\mathrm{Cu}^{2+}$ and $\mathrm{Al}^{3+}$ : A potential $\mathrm{Cu}^{2+}$ and $\mathrm{Al}^{3+}$ switched YES logic function with an INHIBIT logic gate and a novel solid sensor for detection and extraction of $\mathrm{A}^{13+}$ inos from aqueous solution. Sensors and Actuators B: Chemical, 222, 447, 2016.

41. RAI A., SINGH A.K., TRIPATHI K., SONKAR A.K., CHAUHAN B.S., SRIKRISHNA S., JAMES T.D., MISHRA L. A quick and selective rhodamine based "smart probe" for "signal-on" optical detection of $\mathrm{Cu}^{2+}$ and $\mathrm{Al}^{3+}$ in water, cell imaging, computational studies and solid state analysis. Sensors and Actuators B: Chemical, 266, 95, 2018.

42. XU Z.Q., MAO X.J., WANG Y., WU W.N., MAO P.D., ZHAO X.L., FAN Y.C., LI H.J. Rhodamine 6G hydrazone with coumarin unit: a novel single-molecule multianalyte $\left(\mathrm{Cu}^{2+}\right.$ and $\left.\mathrm{Hg}^{2+}\right)$ sensor at different $\mathrm{pH}$ value. RSC Advances, 7 (67), 42312, 2017.

43. LI M., SUN Y., DONG L., FENG Q.C., XU H., ZANG S. Q., MAK T.C.W. Colorimetric recognition of $\mathrm{Cu}^{2+}$ and fluorescent detection of $\mathrm{Hg}^{2+}$ in aqueous media by a dual chemosensor derived from rhodamine $\mathrm{B}$ dye with a $\mathrm{NS}_{2}$ receptor. Sensors and Actuators B: Chemical, 226, 332, 2016.

44. LI G., BAI L., TAO F., DENG A., WANG L. A dual chemosensor for $\mathrm{Cu}^{2+}$ and $\mathrm{Hg}^{2+}$ based on a rhodamine terminated water-soluble polymer in $100 \%$ aqueous solutiin. The Analyst, 143, 5395, 2018.

45. RAVINDRAN S., TAMBE A.J., SUTHAR J.K., CHAHAR D.S., FERNANDES J.M., DESAI V. Nanomedicine: Bioavailability, biotransformation and biokinetics. Current Drug Metabolism, 20 (7), 542, 2019.

46. JAIN S., ZHARIKOVA O.L., RAVINDRAN S., NANOVSKAYA T.N., MATTISON D.R., HANKINS G.D.V., AHMED, M.S. Glyburide metabolism by placentas of healthy and gestational diabetes. 25 (3), 169, 2008. 
47. LEE M.H., YANG Z., LIM C.W., LEE Y.H., DONGBANG S., KANG C., KIM J.S. Disulfide-cleavage-triggered chemosensors and their biological applications. Chem.Rev. 113 (7), 5071, 2013.
48. OCHOA-HERRERA V., LEON G., BANIHANI Q., FIELD J.M., ALVAREZ R.S. Toxicity of copper ions to microorganisms in biological wastewater treatment systems. Science of the Total Environment, 412, 380, 2011. 
